\title{
Liability, Information, and Anti-fraud Investment in a Layered Retail Payment Structure
}

\author{
Kyoung-Soo Yoon*, Jooyong Jun**
}

The views expressed herein are those of the authors and do not necessarily reflect the official views of the Bank of Korea. When reporting or citing this paper, the authors' names should always be explicitly stated.

\footnotetext{
* Professor, Department of Economics, Daegu University, Tel: +82-53-850-6215, Email: yoonks@daegu.ac.kr. ** Corresponding Author, Economist, Economic Research Institute, The Bank of Korea, Tel: +82-2-759-5430, Email: jooyong@bok.or.kr.
}

Kyoung-Soo Yoon appreciates the financial support from the Bank of Korea. The authors greatly appreciate valuable comments from Jaejoon Han, Kyusoo Kim, and Francisco Rodriguez-Fernandez. All errors are our own. 


\section{Contents}

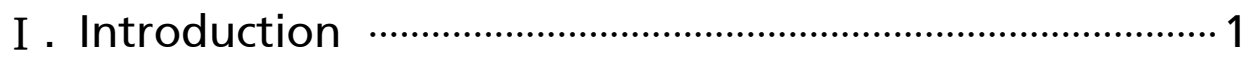

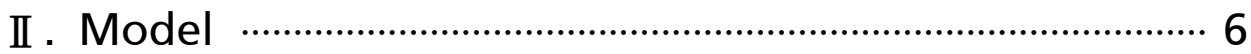

III. Liability and Anti-fraud Investments:

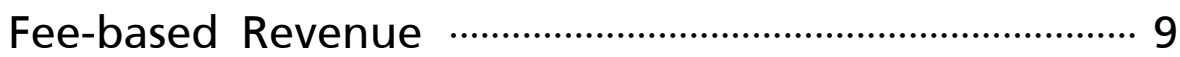

IV. Liability and Anti-fraud investments:

FinTech Business Model ………………………………...16

V. Discussions and Conclusion …………………………….....2 27

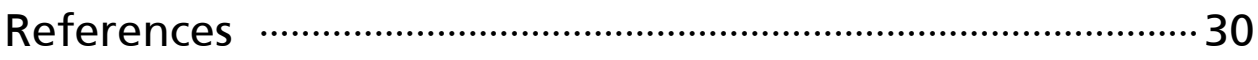

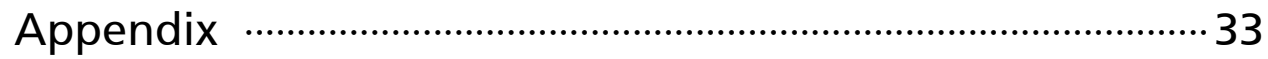




\section{Liability, Information, and Anti-fraud Investment in a Layered Retail Payment Structure}

Motivated by recently introduced retail payment schemes using information technology, often called "FinTech," we examine the effects of fraud liability regime and information accessibility on the incentive for the anti-fraud investment in a vertically separated payment scheme. When the payment service providers make their revenue from consumer fee, it is shown that the anti-fraud investment is made more by parties with liability, and the anti-fraud investment is socially sub-optimal. When the FinTech payment service provider (FPP) makes its revenue other than from counsumer fee, the FPP liability regime leads to greater anti-fraud investment and lower accident probability, compared to the case in raising revenue from consumer fees. The effect under the IPP liability regime, however, is inconclusive. Finally, under certain conditions, the FPP's information accessibility to the IPP's transaction data can enhance the anti-fraud investment and welfare.

Keywords: Payment system, Fraud, Liability, FinTech

JEL Classification: G23, G28, D43, L22 


\section{I . Introduction}

The retail payments landscape is characterized by a wide diversity of payment instruments and activities at each stage of the payment process, which is structured with multiple layers from the front-end services with user interfaces to the back-end services such as settlement and clearing (see Figure 1 in Appendix ${ }^{1)}$ ). A retail payment service provider needs to complete all stages of the payment process. On the other hand, thanks to the tiered structure, the provider does not need to own all the necessary facilities and licenses for processing each stage of the payment chain. Participants in the payment scheme are often non-financial institutions, and they provide services more than technical processes.

Recently, the rapid progress in information and communication technology (ICT) has led to ICT-based retail payments services providing enhanced user experiences, often referred to as "FinTech." Many of the FinTech payment schemes such as Apple Pay and Samsung Pay have the structure of "platform on the platform," and provide a broad range of retail payment services, including offline transactions, based on their user base obtained from their products or services such as mobile devices, operating system, messaging services, and so on. In many cases, a FinTech payment service provider ('FPP' hereafter) provides 'front-end' services only, in cooperation with an incumbent integrated payment service provider ('IPP' hereafter) which has provided the 'end-to-end' type payment services. The IPPs also have worked in cooperation with third parties such as VANs (Value Added Networks), but these third parties are just delegated to take specific technical roles from IPPs, and are mostly invisible to consumers. On the contrary, the FPPs directly interact with consumers, and generate revenue in various ways according to their own business models.2)

1) CPMI (2014) of Bank for International Settlements categorizes the payment process into five stages: (i) pre-transaction, (ii) authorization, (iii) clearing, (iv) settlement, and (v) post-transaction.

2) In a three-party network system (e.g., American Express, Discover, PayPal), an "integrated" platform is relatively clear to be identified. To the contrary, it is often the opposite in a four-party network system (e.g., banks in VISA/Master Card association). Merchant acquirers may be regarded as IPPs described here in the sense that they handle the information and payment flows needed to convert the electronic record created at 
Though the introduction of FinTech payment services is beneficial to end users, it complicates the structure of the retail payment system, which may possibly lead to increasing vulnerability of the payment system security. As the number of interinstitution transfer of information increases, there would be more chance of incidents such as fraudulent transactions and data breaches. ${ }^{3}$ ) Furthermore, the increased number of participants in the payment system also complicates the design of payment schemes to coordinate the participants' incentive on ex-ante investment (and ex-post handling) for the reduction of the financial transaction incidents. As Anderson and Moore (2006) note, the former may be addressed with an engineering approach, but the latter requires an economic approach, which gives implications about the design of an incentive scheme that provides appropriate rights and responsibilities to each participant.

This study examines this problem by investigating the effect of the liability regime and the information accessibility on the investment incentive to reduce the financial accidents in a layered retail payment structure. Obviously, the incentives for anti-fraud investments are closely related to the business model and revenue sharing rules as well as the liability regime, as the FPP may build its own business model other than fee revenue. However, the IPP may refrain from cooperating with the FPP, depending on the FPP's business model and the liability. We present a parsimonious model of vertically separated payment scheme, and compare regimes varying the liability, information accessibility, and the business model of the FPP.

Our theoretical analysis shows that, in a benchmark business model of

the point of sale into cash for the merchant (back-end processing). Unfortunately, the relationships among the entities in the payments network are messy and complicate the transactions process. For example, only a bank is allowed to join Visa or MasterCard network, and, as a result, many merchant acquirers and processors form an alliance or partnership with a sponsoring bank (DeGennaro, 2006). In addition, depending on the merchant's needs, an acquirer might sell front-end processing from any of several companies and/or back-end processing from yet another one. Still, we believe that the our model captures the essentials of effects from the introduction of FPP services provided by ICT companies such as Apple, Google (Android Pay), and Samsung.

3) For example, a sudden increase of frauds related with the Apple Pay was a big issue in March 2015. At one point, a mobile payments advisor said " 6 percent of Apple Pay purchases are completed with stolen cards" (Tsukayama and Halzack, 2015) while others dismiss such claims (Paglier, 2015). 
fee-based revenue, where the revenue is raised from per-transaction usage fee, the anti-fraud investment is made more by parties with the liability, and the investment is socially sub-optimal. We then turn our focus on more realistic business model of FinTech payments services. The FPP may be able to make its revenue other than from the consumer fee, and the IPP may be able to raise the revenue from effective lump-sum fee, or fixed per-transaction fee. In this case, the FPP is interested in increasing its user base. Depending on the business model, it is possible that either (i) only the size of user base matters (complementary sales model; e.g., the case of device manufactures for products sales increase), or (ii) both the quality and quantity user data matter (information extraction model; e.g., the case of software platform providers for personalized surplus extraction). For the latter case, the FPP can increase its revenue from the personalized surplus extraction of users, which is possible only when the access to the transaction information that the IPP collects is allowed. We show that in this business model, without a lump-sum transfer or fixed rent to the IPP, only the FPP liability regime is viable, and the IPP has little incentive for anti-fraud investment. On the other hand, with the transfer or rent, both the IPP and the FPP make equal or more investments in equilibria than under the fee-based revenue model. Under the IPP liability regime, it invests more in equilibrium than in the fee-based revenue model while the FPP invests the equal (complementary sales model) or less amount (information extraction model).

The result is consistent with the observation from the market. Google Wallet, launched in 2011, has never gained any momentum partly because banks are reluctant to share the consumers' payment information with Google. On the contrary, Apple Pay, launched in 2014, does not keep such information and has shown the more successful result so far. ${ }^{4)}$ Under the FPP liability regime, the FPP of both models invest more. The effect on the IPP's profit, however, is

4) Like Apple, Google also has its tokenization technology, called Host Computer Emulation (HCE), which isolates the payment information from a device. Google had not, however, adopt it until the launch of Android Pay in 2015. Some argue that Google's advertisement-based business model hindered the adoption of tokenization technology (Hwang, Kim, and Lee, 2015). 
uncertain. It may be lower than the IPP's profit in the fee revenue model, which implies that the IPP may be reluctant to cooperate with the FPP in this business model. Finally, it depends on the exogenous property of accident prevention technology, whether or not the equilibrium investment under the complementary sales is greater than that under the information extraction models.

Our results provide a policy implication that the information accessibility and fraud liability should go together. To put it another way, the information accessibility would better be given to the FPP, and the regime should include the FPP liability, both of which are not always legally possible.5) Information in a payment scheme include user identities/characteristics, user credit history, and transaction records. Many FinTech service providers, while many of them are not allowed to have users financial and transactional records under current circumstances, are positioned to have better understanding about the user characteristics than the traditional payment service providers. Considering that the FinTech service providers can create value from synergy effects of information convergence, by combining fraud liability for the party with information accessibility, the internalization of security investment externality can be achieved.

Varian (2004) and, more recently, Creti and Verdier (2014) identify the public good nature of information security in the sense that there is a positive spillover effect, which leads to the free-riding problem within the payment system. As for the investment decisions by participants of a "system," Varian (2004) is the first one to analyze the reliability of information systems using a public-good, game-theoretic framework, following the model of Hirshleifer (1983), known as "weakest-link or best shot." Varian adds a third case of sum-of-efforts and shows that sum-of-efforts is the best, while weakest-link is the worst of all. His analysis also tells us that as more agents are added, systems become more reliable in the total-effort case, but less reliable in the weakest-link case. We also adopt this approach and propose an internalizing scheme of the externality in information security where a FinTech payment service provider

5) For example, in Korea, FinTech service providers cannot be liable nor have user information unless they have a separate financial institution license. 
exists as a front-end, or downstream, service provider.

Several theoretical analyses of data breach present equilibrium results where the welfare is not maximized without regulation. Schreft (2007) examines whether or not the markets could limit the risk that identity theft poses to the payment system and finds that the markets fail to curtail this risk due to existing market imperfections. Kahn and Roberds (2008) study identity and its use in credit transactions to find the equilibrium incidence of identity theft, which represents a tradeoff between the necessity to control transaction fraud and the wish to avoid intrusive monitoring of individuals. The results indicate that advances in technology will not diminish this tradeoff in equilibrium. Roberds and Schreft (2009) explore the implications of networks' collection of personal information data, data security, and costs of identity theft using a monetary-theoretic model. They find that too much data collection and too little security arise in equilibrium with non-cooperative networks compared with the efficient allocation. They propose potential regulatory policies such as mandated security levels and data-breach costs reallocation. Anderson and Moore (2006) and Sullivan (2013) also consider similar issues.

The structure of the electronic payment system with vertical separation is investigated in Rochet and Tirole (2003), Rochet (2007), Rochet and Tirole (2011), and Armstrong (2006).6) Jun and Yeo (2016) directly focus on the impact of the introduction of FinTech service added to the vertical structure of payment scheme. While the focus of these studies are the changes in competitive environments in retail payments markets, we focus more on the investments on the security and welfare, and, for this purpose, abstract the 'two-sidedness' from models of the previous literature.

Our study is most similar to the analysis of Creti and Verdier (2014), who examine the effects of liability regimes on the anti-fraud investments. They show that the price structure is biased in favor of participants without liability, and the social welfare is maximized when consumers are without liability. The results are derived from the assumption that the anti-fraud investment can be made only by the merchant, while liability is imposed either on the platform or

6) For survey of the papers and policy implications, see Yoon (2014). 
on the consumer. Though Creti and Verdier (2014) raise important and interesting issues, they do not consider the vertically separated payment scheme and, thus, the allocation of liability as we do.

The rest of this paper is organized as follows. We propose a model of a multilayered payment scheme in section 2. In section 3 , in benchmark case of the fee-based revenue model, the equilibrium investment decisions depending on the liability regimes are examined. In section 4, we extend the model to incorporate the real world business model of the FPP. One of the key issues in the section is the effect of information accessibility. The final section concludes and discusses the specifications of the model used in this paper for future research.

\section{Model}

There are two types of service providers, each of which is denoted by $j \in J=\{I, F\}$, in the market for the retail payment: $j=I$ is the integrated payment platform(IPP, hereafter) and $j=F$ is the FinTech payment service provider(FPP, hereafter). In the traditional electronic payment system, the IPP alone provides the retail payment service, while in the newly introduced payment system, which we call 'FinTech Payment Service(FPS),' both of service providers jointly provides the service. It is assumed that, before the introduction of FPP, the IPP was the monopolistic payment service provider. It provides core functions for payment such as payment approvals, clearings, settlements, and so on. It also provides services for merchants and consumers in the traditional electronic payment scheme such as payment card. For simplicity, we assume there is no issuer and acquirer in the model, that is, the platform is vertically integrated in the traditional payment scheme providing 'end-to-end services'. On the other hand, in the FPS, the payment system is vertically separated. We assume the FinTech service provider enters the payment service market as a front-end service provider. It mainly provides services for the merchant and the consumer, while the IPP also provides core back-end functions. We further assume there is no cost, both for the IPP and the FPP, to provide the FPS, which 
does not affect the qualitative results of the paper.

There are two users of the retail payment service; the consumer and the merchant. From a transaction, the consumer enjoys two types of benefits. First, she gets the consumer surplus from the good/service he purchases, which we assume constant. Secondly, she enjoys the benefit from payment using FPS over using the traditional payment instrument, denoted by $\mathrm{b}$. The benefit is mainly due to the reduction of the transaction cost. Following Rochet and Tirole (2003) and Rochet and Tirole (2011), the benefit is assumed to be probabilistic. For simplicity, we further assume the distribution is uniform on $[0, \bar{b}]$, i.e., the distribution function is $H(b)=b \cdot 1[0, \bar{b}] .7)$

Regarding the merchant, we apply 'price coherence' on the price for products the merchant sells. That is, the merchant cannot discriminate the prices conditional on the payment instrument the consumer decides to use. ${ }^{8)}$ In addition, we assume the merchant gets no benefit from the adoption/acceptance of the FPS. It follows that the IPP and/or the FPP cannot charge any fee on the adoption/acceptance of the FPS. ${ }^{9)}$ Finally, we also assume that the merchant has no option to invest in the transaction security.

The IPP charges fixed per transaction fees for the traditional payment service only on the merchant. In contrast, the FPP is assumed to charge fees for the usage of the FPS, denoted by $f$, on consumers. A portion of the consumer fee, $\mu(0<\mu<1)$, is assumed to be transferred to the IPP for its provision of core back-end functions for transaction processing to the FPP.

For a transaction with the FPS, there is a probability of transaction accident, denoted by $x$, that the security or integrity of a transaction is breached, potentially exacerbated by the use of FPS. We assume that when an accident

7) May need to mention on the general case such as $\mathrm{H}$ with monotone hazard rate.

8) In Rochet and Tirole (2011), the price coherence is the equilibrium outcome. In many countries in past years, it had been implemented by the network rule made by the payment platform, so called "no surcharge rule," until competition authorities and courts prohibits it. In Korea, no surcharge rule is legal regulation. We assume, even without such regulation or network rule, the price coherence holds mainly due to the competition among merchants.

9) The payment providers may charge fees to the merchant for some technical reasons. Charging the fee on the consumer and on the merchant may make different effects because of the indirect network effect. This is an interesting question, but beyond our research, which we leave for future research topic. 
occurs, the loss $L>0$ is incurred, which should be recovered by the liable party. We consider the full liability regimes, either the integrated payment platform liability regime or the FinTech service provider liability regime. Under the regimes, the participant who has the liability is fully responsible for the recovery of the loss. We also consider the partial liability regime, or the proportional liability regime under which each service provider in the FPS is liable for the loss proportional to the share of the revenue $\mu$ for the IPP and $1-\mu$ for the FPP.

Some of transaction accidents can be prevented when participants invest on the payments security. We let $p\left(e_{I}, e_{F}\right)$ be the multi-variate function of the probability that the transaction accident is prevented with the investment $e_{j}(j \in\{I, F\})$ by participants. Let $e=\left(e_{I}, e_{F}\right)$. Then, $L x(1-p(e))$ is the expected loss per transaction. With no investment, $p(0)=0$ is assumed and then the expected loss will be $L x$. We assume the property of $p(\cdot)$ as follows:

Assumption 1 The probability that the transaction accident is prevented with investment e, $p(e)$ satisfies;

$$
\begin{aligned}
\text { i) } p_{j} & >0 \text { for all } j=1,2, \\
\text { ii) } p_{j j} & <0 \text { for all } j=1,2, \\
\text { iii) } p_{12} & =p_{21}>0
\end{aligned}
$$

where $p_{j}$ is the partial derivative w.r.t.j $j^{\prime}$ th coordinate, and $q_{i j}$ is the second derivative w.r.t. $j$ when $i=j \in\{1,2\}$ and cross derivative when $i \neq j$.

The second assumption implies diminishing returns to the investment, and the third assumption implies the efforts by each service provider are either strategic complements in reducing fraudulent transactions. For example, given $0 \leq e_{I}, e_{F} \leq 1 ; p\left(e_{I}, e_{F}\right)=\sqrt{e_{I}} \sqrt{e_{F}}$ satisfies the assumption. The strategically complimentary investments is a mild version of the weakest link case in Varian (2004), is required for the existence of the equilibrium. ${ }^{10)}$ For

10) We can also think of the strategically substitutable investments, which is a mild version of the best-shot case in Varian (2004). For example, $p\left(e_{I}, e_{F}\right)=\left(e_{I}+e_{F}\right) /\left(1+e_{I}+e_{F}\right)$ satisfies (1), (ii), and $p_{12}=p_{21}<0$. 
notational convenience, we sometimes use a function $q(e) \equiv 1-p(e)$ instead of $p$, which is the probability that the transaction accident is not prevented with investment $e$. It is straightforward from the assumption that $q_{j}<0, q_{j j}>0$, and $q_{12}<0$ for all $j=1,2$.

Although a consumer is not responsible for the recovery of the loss, she suffers disutility when she gets related to a fraud. Such disutility may reflect the non-monetary cost, such as the time for the recovery of the financial loss and other inconvenience due to the accident. It also reflects the reliability of the payment system. Thus, it is natural to assume that the disutility depend on the probability of the accident $x q(e)$. For simplicity, we assume the disutility is linear, letting $c(x q(e)) \equiv c x q(e)$, where $c$ is a positive constant. ${ }^{11)}$

Timing of the game is as follows: the liability regime, the information accessibility, the business model of the FPP, and sharing rule of the revenue between the IPP and the FPP are given ex-ante. In the first period, participants decide the amount of investment $e_{I}$ and $e_{F}$ simultaneously. After observing the investments, the FPP makes the total revenue according to its business model. In particular, when the revenue is based on the fee collected from the consumer, the FPP decides the fee $f$ in the second period. Finally, the total revenue is shared between the FPP and the IPP according to the predetermined rule, and if an accident occurs, settlement is made according to the liability rule. We adopt Subgame Perfect Nash equilibrium as the solution concept.

\section{Liability and Anti-fraud Investments: Fee-based Revenue}

To see how the liability affects the anti-fraud investment decisions, we first examine the case where the FPP charges explicit per transaction fees from consumers, which are shared with the IPP. We analyze the model of the FPS as

11) It would be more natural to assume $c(\cdot)$ is increasing convex $\left(c^{\prime}>0, c^{\prime \prime}>0\right)$, because as the probability of such accident increases, the reliability of the payment system may be increasingly disrupted. However, the linear assumption does not change the qualitative results while makes the analysis much simpler. 
an option for payment, varying liability regimes turn by turn. We first examine the IPP liability regime.

\section{Integrated payment platform (IPP) liability regime}

Consider first the second stage game to apply backward induction. Given observed $e$ determined in the first stage, the consumer compare the benefit from the usage of the FPP and the cost which is composed of the fee and the cost due to the increased risk of fraud. The FPP confronts the trade-off between decrease in consumer using FPP and increase in the fee. We have the following lemma.

Lemma 1 Given the first stage investment $e=\left(e_{I}, e_{F}\right)$, the second stage Nash equilibrium is the optimal fee $f^{*}$ and threshold consumer $\hat{b}^{*}$ which satisfy

$$
f^{*}(e)=\frac{\bar{b}-c x q(e)}{2}
$$

and

$$
\hat{b}^{*}(e)=\frac{\bar{b}+c x q(e)}{2} .
$$

Proof) The consumer with benefit $b$ would use the FPP if and only if $b-f-c x q(e) \geq 0$. Let the threshold consumer be $\hat{b}$. Then, we have

$$
\hat{b}=f+c x q(e) .
$$

Given that the cost of anti-fraud investment is a sunk cost at the second stage, the second stage surplus of FPP from consumer's usage of the FPS, denoted by $S_{F}$, is

$$
\begin{aligned}
S_{F}(f) & =(1-\mu) \int_{\hat{b}}^{\bar{b}} f d H(b) \\
& =(1-\mu) f \cdot(\bar{b}-\hat{b}) \\
& =(1-\mu) f \cdot(\bar{b}-f-\operatorname{cxq}(e))
\end{aligned}
$$


under the assumption of the uniform distribution of $b$. The surplus maximizing fee is from the first order condition, and the equilibrium threshold consumer is from equation (3), which completes the proof.

Now, consider the first stage game. From the equilibrium fee $f^{*}(e)$ derived in the second stage game, the total surplus $S$ is

$$
S(e)=\int_{\hat{b}^{*}(e)}^{\bar{b}} f d H(b)=\frac{(\bar{b}-c x q(e))^{2}}{4} .
$$

Then, the surplus for $j=I, F$, is $S_{j}=\mu_{j} S(e)$. Anticipating the equilibrium fee and resulting surplus in the second stage, the $\operatorname{IPP}(I)$ and the $\operatorname{FPP}(F)$ choose their level of anti-fraud investment. The profit function depends on who is liable for the loss. Under the IPP liability regime, the profits of IPP and FPP, denoted by $\Pi_{I}$ and $\Pi_{F}$, respectively, are as follow:

$$
\begin{aligned}
\Pi_{I} & =\mu S(e)-\int_{\hat{b}^{*}}^{\bar{b}} \operatorname{Lxq}(e) d H(b)-e_{I} \\
& =\mu \frac{(\bar{b}-c x q(e))^{2}}{4}-\frac{\bar{b}-c x q(e)}{2} \operatorname{Lxq}(e)-e_{I},
\end{aligned}
$$

and

$$
\Pi_{F}=(1-\mu) S(e)-e_{F}=(1-\mu) \frac{(\bar{b}-c x q(e))^{2}}{4}-e_{F}
$$

The best response is derived from the first order condition of $\Pi_{I}$ and $\Pi_{F}$, and the Nash equilibrium of the first stage game is, as long as it exists, derived from the simultaneous equation of the two first order conditions. The following proposition characterizes the equilibrium. The proof is presented in.

Proposition 1 Suppose that the probability of accident $x$ is sufficiently small so that $\bar{b}>2 c x(1-p(e))$ for all $e$. Then, under the IPP liability regime, for a sufficiently small probability of accident $x>0$, the Nash equilibrium $e^{*}=\left(e_{I}^{*}, e_{F}^{*}\right)$ of the first stage game exists, derived from the first order conditions, and satisfies the following equations; 


$$
\begin{aligned}
& \text { i) } \frac{\mu c x}{2}\left(\bar{b}-c x q\left(e^{*}\right)\right) p_{1}\left(e^{*}\right)+\frac{L x}{2}\left(\bar{b}-2 c x q\left(e^{*}\right)\right) p_{1}\left(e^{*}\right)=1 \\
& \text { ii) } \frac{(1-\mu) c x}{2}\left(\bar{b}-c x q\left(e^{*}\right)\right) p_{2}\left(e^{*}\right)=1
\end{aligned}
$$

Proof) See Appendix A2.

With large $x>0$, the cost from the increasing risk of FPS overwhelms the benefit from its usage, and the optimization problem has a corner solution in which no consumer use FPP in equilibrium. Note that as $x$ and L increases, both of the best response functions of both service providers are upward moving, which implies that the investments level of both service providers increase. In addition, other things being equal, as $\mu$ increases, the best response function of the IPP moves upward while the best response function of FPP moves downward, which leads to the increase in the investment by the IPP and the decrease by the FPP. This suggests that the party with high bargaining power in sharing the surplus invests more.

The effect of the anti-fraud investments can be decomposed of three effects. To further study this, consider the partial derivative of $\Pi_{I}$ with respect to $e^{I}$;

$$
\begin{aligned}
\frac{\partial \Pi_{I}}{\partial e^{I}}= & \underbrace{\frac{\mu c x}{2}(\bar{b}-c x q(e)) p_{1}(e)}_{\text {indirect marginal effect }}+\underbrace{\frac{L x}{2} p_{1}(e)}_{\text {direct marginal effect }} \\
& \underbrace{-L \operatorname{cx}^{2} q(e) p_{1}(e)}_{\text {interacted } \text { effect }}-\underbrace{1}_{\text {marginal cost }} .
\end{aligned}
$$

The first term is the indirect effect of the investment, where higher anti-fraud investment induces more consumer to use the FPP, and the FPS can charge higher fee at the same time. The second term is the direct effect of the investment reflecting the reduction of expected liable loss due to the investment. The third term is the interacted effect where the anti-fraud investment induces more consumers, which increases the expected loss from the 
fraudulent transactions. The second term is positive while the third term is negative, but with sufficiently small $x>0$, the sum of the second and third terms is positive.

The optimal choice of the FPP in the first stage is similar to that of the IPP, except for that the FPP is not responsible for the loss, as we can see on the following decomposition. Note that there is no direct effect for the FPP.

$$
\frac{\partial \Pi_{F}}{\partial e^{F}}=\underbrace{\frac{(1-\mu) c x}{2}(\bar{b}-\operatorname{cxq}(e)) p_{2}(e)}_{\text {in direct marginal effect }}-\underbrace{1}_{\text {marginal cost }} .
$$

By the Assumption 1, i), the direct marginal effect of the investment by the IPP, $\operatorname{Lxp}_{1}\left(e^{*}\right)$, is positive, which implies that, given equal share of the $\operatorname{surplus}(\mu=1 / 2)$, the best response function of the IPP is higher than that of the FPP. Thus, the equilibrium investment by the IPP is higher than that by the FPP. We have the following corollary.

Corollary 1 Under the IPP liability regime, the anti-fraud investment level by each payment service provider is increasing in the probability of the accident, the size of the loss, and the portion that it gets from the surplus. With the equal share of the surplus, the IPP invests more than the FPP.

\section{FinTech payment platform (FPP) liability regime}

The FPP liability regime is symmetric with the IPP liability regime. The second stage game is identical to what we have shown in the previous subsection, and in the first stage game, the only difference lies in who is liable for the loss. We state the equilibrium and the implication without further explanation.

Proposition 2 Under the FPP liability regime, for sufficiently low $x>0$, the Nash equilibrium $e^{*}=\left(e_{I}^{*}, e_{F}^{*}\right)$ of the first stage game exists and satisfies the following equations; 


$$
\begin{aligned}
& \text { i) } \frac{\mu c x}{2}\left(\bar{b}-c x q\left(e^{*}\right)\right) p_{1}\left(e^{*}\right)=1 \\
& \text { ii) } \frac{(1-\mu) c x}{2}\left(\bar{b}-c x q\left(e^{*}\right)\right) p_{2}\left(e^{*}\right)+\frac{L x}{2}\left(\bar{b}-2 c x q\left(e^{*}\right)\right) p_{2}\left(e^{*}\right)=1
\end{aligned}
$$

Corollary 2 Under the FPP liability regime, the anti-fraud investment level by each payment service provider is increasing in the probability of the accident, the size of the loss, and the share from the surplus. With the equal share of the surplus, the FPP invests more than the IPP.

\section{Social optimum and efficiency of the market equilibrium}

Now, we examine how the equilibrium anti-fraud investments are distorted from the social optimum. Suppose that the demand is not affected by payment method (i.e. no usage externality). Then, the social welfare function SW from the introduction of the FinTech payments service can be defined as

$$
S W(e, \tilde{b})=\int_{\tilde{b}}^{\bar{b}} b-(c+L) x q(e) d H(b)-e_{I}-e_{F},
$$

which is the sum of the consumer surplus and the surpluses of two service providers.

From the first order condition, the socially optimal threshold consumer $\tilde{b}^{S O}$ must satisfy $\tilde{b}^{S O}=(c+L) x q\left(e^{S O}\right)$ where $e^{S O}=\left(\left(e^{I}\right)^{S O},\left(e^{F}\right)^{S O}\right)$ represents the socially optimal investment by each participant. Different from the market equilibrium, the threshold depends on the loss from the fraudulent transaction.

Given the socially optimal threshold $\tilde{b}^{S O}$, by Leibnitz's Rule, the optimal investments by $j=I, F$ must satisfy the following first order conditions

$$
\partial S W / \partial e_{j}=(c+L) x\left(\bar{b}-\tilde{b}^{S O}\right) p_{j}(e)-1=0
$$

which leads to the following equation 


$$
(c+L) x\left(\bar{b}-(c+L) x q\left(e^{S O}\right)\right) p^{j}\left(e^{S O}\right)-1=0 .
$$

To figure out the social optimality of the equilibrium investment under a certain regime, we need to compare equilibrium value of $q\left(e^{*}\right)$ with socially optimal value of $q\left(e^{S O}\right)$. Typical comparisons under externality of the marginal social benefit/cost and the marginal private benefit/cost would help determine the optimality of the investments. Consider equations (7) and (8) in Proposition 1 under the IPP liability regime. Because the marginal social cost in (12) and the marginal (private) cost of the investment in (7) and (8) are identical, it suffices to compare the marginal social benefits and marginal private benefits. The following Proposition shows that, in most cases, the marginal social benefit for each service provider is higher than the marginal private benefit, which leads to the social sub-optimality of the anti-fraud investments.

Proposition 3 With the equal share of the surplus, the anti-fraud investment is socially sub-optimal under the IPP and FPP liability regime.

Proof) Let $M B_{j}^{S}(e)$ be the marginal benefit from (12), and $M B_{j}^{P}(e)$ be the marginal benefit from Proposition 1 for $j=I, F$. Then, we have

$$
\begin{aligned}
\Psi_{I}(e) \equiv & M B_{I}^{S}(e)-M B_{I}^{P}(e) \\
= & \frac{(2-\mu) c x}{2}(\bar{b}-c x q(e)) p_{1}(e)+\frac{L x}{2}(\bar{b}-c x q(e)) p_{1}(e) \\
& \quad-L^{2} x^{2} q(e) p_{1}(e) \\
\Psi_{F}(e) \equiv & M B_{F}^{S}(e)-M B_{F}^{P}(e) \\
= & \frac{(1+\mu) c x}{2}(\bar{b}-c x q(e)) p_{1}(e)+L x(\bar{b}-(c+L) x q(e)) p_{1}(e)
\end{aligned}
$$

For the FPP, $\Psi_{F}>0$ for all e, which implies that it has lower incentive under the IPP liability regime than socially desirable. For the IPP, the effect on the 
incentive is ambiguous due to the third term of (13). However, the gab between the marginal social benefit and the marginal private benefit is smaller for the IPP than the FPP, in most cases. To make the comparison easier, let $\mu=1 / 2$. Then, $\left|\Psi_{I}\right|<\left|\Psi_{F}\right|$ because $\bar{b}-c x q(e)>0$ for all $e$. Combining this fact with the complementary property of $p(e)$, we can conclude that the $p\left(e^{*}\right)$ is lower than $p\left(e^{S O}\right)$, that is, the equilibrium anti-fraud investment is sub-optimal under the IPP liability regime.

The formula $\Psi_{j}$ in the proof represents the distortion of the equilibrium outcome from the social optimum. The first terms in (13) and (14) show the direct distortion resulted from the monopoly pricing by the FPP. The second terms in (13) and (14) are the direct distortions resulted from the lack of liability on the FPP. The third term (13) is the interacted distortion from the side of FPP. The logic can be applied to the FPP liability regime as well.

\section{Liability and Anti-fraud Investments: FinTech Business Model}

\section{FinTech business models: overview}

In the previous section, we examine the effect of the liability regime on the anti-fraud investments. In doing so, we presume that the IPP and the FPP make their revenues from the fee on the consumer. As noted in the introduction, however, the FPS is characterized as a platform on the platform in a layered payment structure, and the FPP's business model in real world is different from what is described in the previous section. More often than not, the FPP makes its profit from 'convergence of platform' rather than traditional fee based surplus.

In this line, the FPP's first objective is to increase the consumer base because its profits is indirect, and depends on how smart the FPP can use its own platform base. Among others, there are two prominent types of business model for the FPPs. The FPP may be able to raise revenue from consumer fee, but the provision of FPS is often expected to play the role of 
(i) (Complementary sales model) a complementary feature which contributes the increase of their revenue in the device sales (e.g. Apple Pay, Samsung Pay), or

(ii) (Information extraction model) a source of information, derived from the FPS usage data, for the platform business (e.g. Google Wallet/Android Pay). for the FPP.

While the FPP's does not necessarily need user information for its (indirect) additional gain from device sales to consumers in case (i), in case (ii), when the FPP raises its revenue from platform business using the personal information of the users, the key issue is the accessibility of the payments related information. If the FPP has the right to access the information regarding the transaction records, it has higher chance to incorporate the information to what it already knows; the information regarding the user characteristics. In this case, the FPP can raise its revenue not resorting to the fee by expropriating the transaction benefit from the FPS usage. For example, the operating system providers or internet/mobile portals may increase their profits by personalized advertisements when they can access the transaction data and match them to the personal data. Taking the real world business models of the FPPs into account, we analyze the impact of the liability regimes on the anti-fraud investment in cases of the two FPS business models turn by turn.

One of the important issues in case of FPS business model is whether and how the IPP shares the surplus that the FPP makes. Different from the case of fee-based revenue, the IPP has, at most, imperfect information regarding the surplus or revenue of the FPP, as the revenue from the business model is a rather private information. In one extreme case, the IPP may make no additional revenue from the FPS business, particularly when the side payment is not allowed. On the other hand, there is a possibility that the IPP and the FPP bargain over the surplus from the business. In the latter case, the share of the surplus of the two parties would depend on the bargaining power, and as a result, the incentive for the anti-fraud investment makes the analysis complicated. As a reasonable benchmark, we consider the case in which the IPP's share of the surplus is the same as what is expected from the fee-based revenue analyzed in the previous section. 


\section{Anti-fraud investment in a complementary sales model}

\subsection{Without per-transaction rent}

When the FPP raises its revenue from the users who adopts the FPS, its objective is to increase the consumer base. In this case, in the second stage of the game, the equilibrium fee would be $f^{*}=0$, and marginal consumer is $\hat{b}^{*}=c x q(e) .{ }^{12)}$ Now, consider the first stage game. An interesting feature of the model in this case is that, under the IPP liability regime, the IPP would not cooperate with the FPP without monetary transfer other than fee-based revenue share. This is because, the fee is the same as what it charges to the traditional scheme users, raising no revenue, while it incurs costs from increased financial accidents. Thus, let's focus on the FPP liability regime.

Under the FPP liability regime, note that the IPP has no incentive to invest on the prevention of the frauds. Let the revenue of the FPP be proportional to the user base, i.e., $\Pi_{F}=\gamma I\left[b \geq \hat{b}^{*}\right]$, where $I[\cdot]$ is the indication function and $\gamma>0$. Then,

$$
\begin{aligned}
\Pi_{F} & =\int_{\hat{b}}^{\bar{b}} \gamma-L x q(e) d H-e_{F} \\
& =(\bar{b}-\operatorname{cxq}(e))(\gamma-\operatorname{Lxq}(e))-e_{F}
\end{aligned}
$$

and the first order condition gives

$$
\begin{aligned}
\frac{\partial \Pi_{F}}{\partial e^{F}}= & \underbrace{\gamma c x p_{2}(e)}_{\text {indirect marginal effect }}+\underbrace{\operatorname{Lxp} p_{2}(e)}_{\text {direct }} \\
& \underbrace{-2 c x^{2} L q(e) p_{2}(e)}_{\text {inter acted effect }} \underbrace{-1}_{\text {marginal cost }} \\
& =0
\end{aligned}
$$

12) Note that zero fee means the fee is the same as what the traditional electronic payment scheme charges. There is a possibility that the fee is negative, when the FPS provides promotions for the adoption of FPS. We ignore such case. 
Comparing the result with the result in the previous section, the FPP invests more because the effect of the investment on increasing the user base is higher and the revenue is not shared with the IPP. Note, however, that the total anti-fraud investment in equilibrium in comparison with the fee-based model is ambiguous, because it depends on the shape of $p$.

Proposition 4 In a complementary sales model, only the FPP liability regime is viable. In that case, the anti-fraud investment by the FPP is higher than when the FPP raises the revenue from the fee.

\subsection{IPP liability regime with fixed per-transaction rent}

We now examine the case in which the revenue from FPS business model is shared with the IPP, allowing a monetary transfer in the form of fixed per-transaction fee ${ }^{13}$ ). In this case, the IPP has an incentive to cooperate with the FPP even under its liability regime. We first consider this case.

As is the analysis above, in the business model where the revenue is from the FPS adoption; i.e., $S_{F}=\gamma I\left[b \geq \hat{b}^{*}\right], \gamma>0$, the equilibrium consumer fee would be $f^{*}=0$ and the threshold consumer benefit is $\hat{b}^{*}=\operatorname{cxq}(e)$.

Now, consider the first stage game. Given no direct fee revenue, the IPP may be agreed to accept a fixed fee per transaction for the IPP's access to its infrastructure. Denoting the superscript as the liability regime, each payment platform's profits $\pi_{I}^{I}$ and $\pi_{F}^{I}$ are now

$$
\begin{aligned}
\pi_{I}^{I} & =\int_{\hat{b}^{*}}^{\bar{b}}\left(F-\operatorname{Lxq}(e) d H(b)-e_{I}\right. \\
& =(\bar{b}-\operatorname{cxq}(e))(F-\operatorname{Lxq}(e))-e_{I}
\end{aligned}
$$

13) One may think of the fixed lump-sum transfer rather than per-transaction rent. However, the lump-sum transfer does not change the incentive structure from the case without transfer, in which case we are less interested. 
and the FPP's profit $\pi_{F}^{I}$, which comes from the (indirect) increase in the device sales increase, is defined as

$$
\begin{aligned}
\pi_{F}^{I} & =\int_{\hat{b}^{*}}^{\bar{b}}(\gamma-F) d H(b)-e_{F} \\
& =(\gamma-F)(\bar{b}-c x q(e))-e_{F}
\end{aligned}
$$

where $\gamma$ is the value of (indirect) revenue per user.

The IPP's anti-fraud investment $e_{I}$ is affected by the marginal expected loss only, which is determined by the following first order conditions

$$
\frac{\partial \pi_{I}^{I}}{\partial e^{I}}=\left(c x F+L x(\bar{b}-2 c x q(e)) p_{1}(e)-1=0,\right.
$$

and

$$
\frac{\partial \pi_{F}^{I}}{\partial e_{F}}=c x(\gamma-F) p_{2}(e)-1=0 .
$$

For the purpose of comparison, suppose that $\gamma=\frac{\left(\bar{b}-c x q\left(e^{*}\right)\right)^{2}}{4} / \frac{\bar{b}-c x q\left(e^{*}\right)}{2}$ $=\left(\bar{b}-c x q\left(e^{*}\right)\right) / 2$ and $F=\mu\left(\bar{b}-c x q\left(e^{*}\right)\right) / 2$ so that both platforms' revenues per user stay the same as in the previous section. Proposition 5 shows the comparison result.

Proposition 5 In a complementary sales model, under the IPP liability, given an inner solution of the IPP's effort level, $e_{I^{*}}$, obtained with the fee-based revenue case, the IPP's effort level when the FPP pays the per-transaction rent, $e_{I}$, is greater than $e_{I}^{*}$ while the FPP's effort $e_{F}$ is the same as $e_{F}^{*}$.

Proof) The first order condition in Proposition 1,

$$
\left[\frac{1}{2}\left(\mu c x\left(\bar{b}-c x q\left(e^{*}\right)\right)+\operatorname{Lx}\left(\bar{b}-2 c x q\left(e^{*}\right)\right)\right] p_{1}\left(e^{*}\right)=1\right.
$$

implies that $p_{1}\left(e^{*}\right)$, which is positive, must be higher than $p_{1}(e)$ derived from 
equation (18), which can be rewritten as

$$
\left[\frac{1}{2}\left(\mu c x\left(\bar{b}-c x q\left(e^{*}\right)\right)-2 L x(\bar{b}-2 c x q(e))\right)\right] p_{1}(e)=1
$$

after plugging in $\gamma=\left(\bar{b}-c x q\left(e^{*}\right)\right) / 2$ and $\left.F=\mu\left(\bar{b}-c x q\left(e^{*}\right)\right) / 2.14\right)$

On the other hand, equation (19) leads to the same level of effort from the FPP as in equation (6), given $\bar{b}-2 c x q(e)>0$ for the same value of $\gamma$ and $F$. Thus, the effort levels are determined as $e_{I}>e_{I}^{*}$ and $e_{F}=e_{F}^{*}$.

Compared with the result in the previous section, this result is always favorable for the FPP but not always so for the IPP, depending on the shape of $p(e)$. We compare the values of $\pi_{I}^{I}$ and $\pi_{F}^{I}$ here and those in the previous section. The value of $\pi_{I}^{I}$ here is

$$
\frac{\mu}{2}\left(\bar{b}-c x q\left(e^{*}\right)\right)(\bar{b}-c x q(e))-\operatorname{Lxq}(e)(\bar{b}-c x q(e))-e_{I}
$$

while the value of $\pi_{I}^{I}$ in the previous section, equation (5), is rewritten as

$$
\frac{\mu}{4}\left(\bar{b}-c x q\left(e^{*}\right)\right)^{2}-\frac{\operatorname{Lxq}\left(e^{*}\right)}{2}\left(\bar{b}-c x q\left(e^{*}\right)\right)-e_{I}^{*} .
$$

The sum of the first two terms of equation (20) is obviously more than twice the sum of those of equation (21). However, because of the increasing concave assumption on $p(e)$, decreasing the value of $p(e)$ may actually require far bigger increased level of effort $e_{I}$ especially when $p\left(e^{*}\right)$ is sufficiently high. Because of the huge increase in $e_{I}$, the overall result may not be favorable for the IPP under IPP liability regime with the same per-user rent from the FPP as in the previous section.

14) Note that $0<\frac{1}{2} p_{1}\left(e^{*}\right)<p_{1}(e)$. 


\subsection{FPP liability regime with fixed per-transaction rent}

Under the FPP liability regime, the profits of the IPP and FPP, $\pi_{I}^{F}$ and $\pi_{F}^{F}$ respectively, are as follows;

$$
\begin{aligned}
\pi_{I}^{F} & =\int_{\hat{b}}^{\bar{b}} F d H(b)-e_{I}=(\bar{b}-c x q(e)) F-e_{I} \\
\pi_{F}^{F} & =\int_{\hat{b}}^{\bar{b}}(\gamma-F-\operatorname{Lxq}(e)) d H(b)-e_{F} \\
& =(\bar{b}-\operatorname{cxq}(e))(\gamma-F-\operatorname{Lxq}(e))-e_{F}
\end{aligned}
$$

The first order conditions are derived as

$$
\frac{\partial \pi_{I}^{F}}{\partial e_{I}}=-c x F p_{1}(e)-1=0
$$

and

$$
\begin{aligned}
& \frac{\partial \pi_{F}^{F}}{\partial e^{F}}=\underbrace{(\gamma-F) c x p_{2}(e)}_{\text {indirect marginal effect }}+\underbrace{\text { Lxp } p_{2}(e)}_{\text {direct }} \\
& \underbrace{-2 c x^{2} L q(e) p_{2}(e)}_{\text {interacted effect }} \underbrace{-1}_{\text {marginal cost }}=0 .
\end{aligned}
$$

Now we compare the equilibrium efforts with what the result in the fee-revenue sharing case presented in the previous section. Given the same $\gamma=\left(\bar{b}-c x q\left(e^{*}\right)\right) / 2$ and $F=\mu\left(\bar{b}-c x q\left(e^{*}\right)\right) / 2$ as in the IPP liability regime, the IPP puts the same level of effort $e_{I}$ that is determined by the first order condition in Proposition 2. On the other hand, assuming that $\bar{b}-2 c x q\left(e^{*}\right)>0$, the FPP invests more. 
Proposition 6 In a complementary sales model, under the FPP liability regime, the anti-fraud investment by the FPP is higher than when the FPP raises the revenue from the fee.

\section{Anti-fraud investment in a information extraction model}

\subsection{Without per-transaction rent}

When the FPP raises its revenue from platform business using the personal information of the user benefit, the key issue is the accessability of the information. If the FPP has the right to access the information regarding the transaction records, it has higher chance to incorporate the information to what it already knows; the information regarding the user characteristics. In this case, the FPP can raise its revenue not resorting to the fee by expropriating the transaction benefit from the FPS usage. For example, the operating system providers or internet/mobile portals may increase their profits by personalized advertisements when they can access the transaction data and match them to the personalized data. Such surplus extraction without fee charges, of course, can be made without transaction data, as long as the FPP knows the transaction benefit distribution. However, it is clear that the transaction data help the FPP to extract the surplus based on the personalized benefit. In this case, in a sense, the fee structure would be similar to the two-part tariff by the monopolist. The FPP then has an incentive to lower the fee and raise the revenue from other sources. In addition, the accessibility may increase the productivity of the anti-fraud investment by the FPP.

To capture the idea, we consider an extreme case; in the second stage game, the FPP can extract full user surplus, letting the fee as lower as possible. Then, the equilibrium fee would be $f^{*}=0$, and marginal consumer is $\hat{b}^{*}=c x q(e)$, the same as the case of the previous subsection.

Now, consider the first stage game. Again, the IPP would not cooperate with the FPP without lump-sum transfer under the IPP liability regime. Focusing on the FPP liability regime, the profit of the FPP is 


$$
\begin{aligned}
\Pi_{F} & =\int_{\hat{b}}^{\bar{b}} b-\operatorname{Lxq}(e) d H-e^{F} \\
& =\frac{\bar{b}^{2}-c\left(x q\left(e^{F}\right)\right)^{2}}{2}-\left(\bar{b}-c x q\left(e^{F}\right)\right) \operatorname{Lxq}\left(e^{F}\right)-e_{F}
\end{aligned}
$$

and the first order condition gives

$$
\begin{aligned}
\frac{\partial \Pi_{F}}{\partial e_{F}}= & \underbrace{c x}_{\text {indirect }{ }_{\text {marginal effect }}^{c x q(e) p_{2}(e)}}+\underbrace{L x p_{2}(e)}_{\text {direct marginal effect }} \\
& \underbrace{-2 c x^{2} L q(e) p_{2}(e)}_{\text {interacted effect }} \underbrace{-1}_{\text {marginal cost }} \\
& =0
\end{aligned}
$$

Comparing the result with the result without information accessibility, the FPP invests more when it has accessibility because the effect of the investment on increasing the user base is high and the revenue is not shared with the IPP. If we assume the productivity of anti-fraud investment is higher with information accessibility than without it, we can easily see that there is bigger investment incentive for the FPP in the former case. Note, however, that the effect of the information accessibility on the total anti-fraud investment in equilibrium is ambiguous, which depends on the shape of $p$.

Proposition 7 In a information extraction model, without monetary transfer, the IPP would not allow the information accessibility under the IPP liability regime. The FPP increases the anti-fraud investment when information accessibility is allowed.

\subsection{IPP liability regime with fixed per-transaction rent}

Again, when the revenue from exploitation of the transaction data is shared with the IPP, the IPP has an incentive for the anti-fraud investment even under the IPP liability regime. As long as the same fixed per-transaction rent is paid, 
the investment incentive for the IPP is exactly the same as the case of FPS adoption case in the previous subsection. Thus, it is enough to analyze the anti-fraud incentive for the FPP.

Under the IPP liability regime, $\pi_{I}^{F}$, the profit from the exploit of the user information is defined as

$$
\begin{aligned}
\pi_{F}^{I} & =\int_{\hat{b}}^{\bar{b}}(b-F) d H(b)-e_{F} \\
& =\frac{\bar{b}^{2}-(c x q(e))^{2}}{2}-(\bar{b}-c x q(e)) F-e_{F},
\end{aligned}
$$

and the first order condition gives

$$
\frac{\partial \pi_{F}^{I}}{\partial e^{F}}=c x(c x q(e)-F) p_{2}(e)-1=0 .
$$

For the purpose of comparison, suppose that $\gamma=\frac{\left(\bar{b}-c x q\left(e^{*}\right)\right)^{2}}{4} / \frac{\bar{b}-c x q\left(e^{*}\right)}{2}$ $=\left(\bar{b}-c x q\left(e^{*}\right)\right) / 2$ and $F=\mu\left(\bar{b}-c x q\left(e^{*}\right)\right) / 2$ so that both platforms' revenues per user stay the same as in the previous section. Proposition 8 shows the comparison result.

Proposition 8 In a information extraction model where the FPP pays fixed pertransaction fee to the IPP, given an inner solution of the IPP's effort level, the IPP's effort level, $e_{I}$, is greater than $e_{I}^{*}$, while the FPP's effort $e_{F}$ is smaller than $e_{F}^{*}$, where $e_{j}^{*}$ 's are obtained from the fee-based revenue case.

Proof) The first part of the Proposition regarding the IPP's effort level is exactly same as one in Proposition 5. On the other hand, equation (26) leads to the lower level of effort from the FPP, given $\bar{b}-2 c x q(e)>0$ for the same value of $F$. Thus, the effort levels are determined as $e_{I}>e_{I}^{*}$ and $e_{F}<e_{F}^{*}$. 
As in the case of a complementary sales model, the result is always favorable for the FPP but not always so for the IPP. Moreover, in the information extraction model, the IPP will get worse off than in case of the FPS adoption due to the decrease in the FPP's level of effort $e_{F}<e_{F}^{*}$.

\subsection{FPP liability regime with per-transaction rent}

Under the FPP liability regime, the profit of the IPP is the same as in the case of revenue from the FPS adoption, while the profit of the FPP $\pi_{F}^{F}$ is

$$
\begin{aligned}
\pi_{F}^{F} & =\int_{\hat{b}}^{\bar{b}} b-F-\operatorname{Lxq}(e) d H(b)-e_{F} \\
& =\frac{\bar{b}^{2}-(c x q(e))^{2}}{2}-(\bar{b}-c x q(e))(F+\operatorname{Lxq}(e))-e_{F},
\end{aligned}
$$

of which the first order condition is

$$
\begin{aligned}
& \frac{\partial \pi_{F}^{F}}{\partial e^{F}}=\underbrace{(c x q(e)-F) c x p_{2}(e)}_{\text {indirect marginal effect }}+\underbrace{\operatorname{cx} \underbrace{\operatorname{Lxp} p_{2}(e)}_{\text {marginal effect }}}_{\text {direct }} \\
& \underbrace{-2 c x^{2} L q(e) p_{2}(e)}_{\text {interacted } \text { effect }} \underbrace{-1}_{\text {marginal cost }}=0 .
\end{aligned}
$$

Comparing the equilibrium efforts with the result in fee-based revenue case, given the same $F=\mu\left(\bar{b}-c x q\left(e^{*}\right)\right) / 2$ as under the IPP liability regime, the IPP puts the same level of effort $e_{I}$ that is determined by the first order condition in Proposition 2. Moreover, if the inequality $2 c x q\left(e^{*}\right)<\bar{b}<2 c x q(e)+c x q\left(e^{*}\right)$ is satisfied, the value of $e_{F}$ increases even bigger in this case. This inequality also implies that $q(e)>q\left(e^{*}\right) / 2$, which can be satisfied depending on the curvature of $q(e)$. If the last inequality is not satisfied, the FPP's investment in the case of personalized surplus extraction model is smaller than that in case of FPS adoption model. However, this result may not be unsatisfactory, although not optimal, because the value of failed transactional accident prevention probability is lowered by more than half. 
Proposition 9 In an information extraction model, under the FPP liability regime, the anti-fraud investment by the FPP is higher than when the FPP raises the revenue from the fee. Furthermore, the FPP's investment is bigger than the investment in the case of a complementary sales model.

\section{Discussions and Conclusion}

In this paper, based on a parsimonious payment platform model with vertical separation, we characterize the anti-fraud investment decisions in equilibrium. We show that, under full liability regime in a fee-based revenue model, the anti-fraud investment is made more by parties with the liability and with higher bargaining power, and the anti-fraud investment is socially sub-optimal. When the FPP raises its revenue other than from the usage fee, without a monetary transfer from the FPP to the IPP, the IPP would cooperate with the FPP only under the FPP liability regime, in which case the FPP increases the anti-fraud investment. When per-transaction rent is paid to the IPP, the FPP liability regime leads to the higher anti-fraud investments and lower accident probability compared to the fee-based revenue model. In particular, when the business model of the FPP is based on the information extraction, the FPP's accessibility to the transaction information can enhance the anti-fraud investment and welfare. The result of our study suggests that policy intervention might be needed for the information accessibility and fraud liability to work in mutual balance.

There are a few issues for future research. First of all, the model in this paper is based on the assumption that the anti-fraud investments by two service providers are strategic complements. This may not always hold, especially when the duplicated investments are wasteful. For example, Varian (2004) considers three cases regarding the way that efforts exerted by participants of the system affects the system reliability: 'sum of efforts,' 'weakest-link' where it depends on the minimum effort, and 'best-shot' where the reliability depends on the maximum effort. The first two cases are extreme cases of our model, while the 
third case is not analyzed through our model. To examine the equilibrium of the case, we need to consider model in which the anti-fraud investments are strategic substitutable, not complementary, modifying the Assumption 1, iii). However, in this case, the monotonicity of the best response functions are not guaranteed, nor are the existence and uniqueness of the equilibrium.

In addition, for tractability of the analyses, we present very simplify the vertical structure, abstracting several issues. We assume that the surplus from fee on the usage of the FPP is divided between the IPP and FPP according to the exogenous ratio. The assumption presumes the bargaining situation, where the ratio reflects the bargaining power. There are, however, other situations that the presumption does not hold. For example, the IPP may first charge the fee on the provision of the core functions such as authentification, clearing, and settlement, and then the FPP decides the fee on the usage of the FPS. In this case, there would be the double marginalization problem in the second stage, which results in higher fee and narrower consumer usage. We also abstract the two-sidedness of the payment platform by assuming the fee for the usage of the FPS is imposed only on the consumer. Our model is a simplified version of 'macro' model in terms of Economides (1996), and the margin and bargaining power are exogenously given, not solved in the model. This leads to the lack of analysis on the (relative) price charged on the consumer and merchant, which is one of the important issues in payment system. We assume the perfect pass-through, implicitly implying that the merchant can discriminate the price between consumers using traditional payment instrument and those using FinTech based payment instrument. This assumption is plausible in some cases, but not universal. Indeed, 'price coherence' is one of the factors from which distorted price structure is resulted. However, because we are not focusing on the inefficiency due to the price distortion, the price coherence problem does not matter for the validity of the results in this paper. Finally ignore the competition between platforms. The analysis on this topic might be crucial to derive policy implications. We leave these issues for future research.

For policy implications, it would be worthwhile to mention a rather traditional issue regarding the liability regimes, not covered in this paper: 
consumer liability versus payment service provider liability. A well-known example about this subject is the ATM fraud liability comparison between the United States and the United Kingdoms. While banks are generally liable for the costs of card fraud in the U.S., the banks could get away in the U.K.. U.K. banks, however, spend more on security and suffer more frauds (Anderson and Moore, 2006). In Korea, consumers are left with liability if they make 'significant' mistakes by law. The 'significance' is often judged by court, and Korea Supreme Court's decisions have often favored the companies' arguments. ${ }^{15)}$ The problem here is that 'significant' mistakes can occur more often than consumers' expectation, and is exacerbated by the use of "National Public Key Infrastructure" security plug-ins on the client side. ${ }^{16)}$ Thus, it is no wonder that Korean banks and credit card companies favor running the security modules on the client side, which can increase the chance of consumer mistakes, but lead to less liability for them, and thus, the introduction of FinTech payments services has been delayed. For example, in 2013, when a major online bookstore in Korea tried to provide an online payment service with the enhanced user experience without the security plug-ins, card companies boycotted the bookstore, and just in two months after the launching, it eventually discontinued the payment service.

15) From Jan 2012 to July 2013, there were 185 lawsuits filed by online financial fraud victims against banks and card companies. Of the 51 final verdicts, plaintiffs lost 49 cases (Park, 2015).

16) NPKI plug-ins had been a standard and requirement for online transactions in Korea for a long time, and still has been dominant until now. 


\section{References}

Anderson, K. B., E. Durbin, and M. A. Salinger (2008), "Identity Theft," Journal of Economic Perspectives, Vol. 22, pp. 171-192.

Anderson, R., and T. Moore (2006), "The Economics of Information Security," Science Vol. 314(5799), pp. 610-613.

Armstrong, M. (2006), "Competition in Two-sided Market," The Rand Journal of Economics Vol. 37(3), pp. 668-691.

Cheney, J. S. (2005), "Identity Theft: Do Definitions Still Matter?" Federal Reserve Bank of Philadelphia Payment Cards Center Discussion Paper.

CPMI (2014), Non-banks in retail payments. Committee on Payments and Market Infrastructures, Bank for International Settlement.

Creti, A., and M. Verdier (2014), "Fraud, Investments, and Liability Regimes in Payment Platform," International Journal of Industrial Organization, Vol. 35, pp. 84-93.

DeGennaro, R. P. (2006), "Credit Card Processing: A Look Inside the Black Box," Economic Review, Vol. 9(1), pp. 27-42.

Economides, N. (1996), "The Economics of Networks," International Journal of Industrial Organization, Vol. 14(6), pp. 673-699.

Hirshleifer, J. (1983), "From Weakest-link to Best-shot: The Voluntary Provision of Public Goods," Public Choice, Vol. 41(3), pp. 371-386.

Hwang, S. K., D. H. Kim, and S. B. Lee (2015), "Industry Issue: FinTech Industry," Kyobo Securities Research Center.

Jun, J. Y., and E. J. Yeo (2016), "Entry of FinTech Firms, and Competition in the Retail Payments Market," Asia-Pacific Journal of Financial Studies, Vol. 45(2), pp. 159-184. 
Kahn, C., and W. Roberds (2008), "Credit and Identity Theft," Journal of Monetary Economics, Vol. 55(2), pp. 251-264.

Koyame-Marsh, R. O., and J. L. Marsh (2014), "Data Breaches and Identity Theft: Costs and Responses," IOSR Journal of Economics and Finance, Vol. 5(6), pp. 36-45.

Paglier, J. (2015), "Apple and Banks Dismiss Apple Pay Fraud Worries," CNN Money.

Park, J. H. (2015), "Proposal for Consumer Protection and Financial Security," In Electronic Financial Transactions Act: Amendment Proposal, pp. 19-40.

Roberds, W., and S. L. Schreft (2009), "Data Breaches and Identity Theft." Journal of Monetary Economics, Vol. 56(7), pp. 918-929.

Rochet, J. C., and J. Tirole (2007), "Competing Payment Systems: Key Insights from the Academic Literature," In the Payments System Review Conference, the Reserve Bank of Australia and the Centre for Business and Public Policy, Melbourne Business School, pp. 5-18.

Rochet, J. C., and J. Tirole (2003), "An Economic Analysis of the Determination of Interchange Fees in Payment Card Systems," Review of Network Economics, Vol. 2(2), pp. 69-79.

- (2011), "Must-Take Cards: and Merchant Discounts and Avoided Costs," Journal of the European Economic Association, Vol. 9(3), pp. 462-495.

Schreft, S. L. (2007), "Risks of Identity Theft: Can the Market Protect the Payment System?" Economic Review, Vol. 92(4), pp. 5-40.

Sullivan, R. J. (2013), "The U.S. Adoption of Computer-chip Payment Cards: Implications for Payment Fraud," Economic Review, pp. 59-87.

Topkis, D. M. (1998), Supermodularity and Complementarity, Princeton University Press.

Tsukayama, H., and S. Halzack (2015), “Apple Pay's Pitch: Simpler is Better. But Some Security Experts Disagree," Washington Post. 
Varian, H. R. (2004), "System Reliability and Free Riding," In Economics of Information Security, Springer U.S., pp. 1-15.

Vives, X. (2001), “Oligopoly Pricing: Old Ideas and New Tools," The MIT Press.

Yoon, K. S. (2014), "Market Structure and Regulation of Payment Card," Korea Journal of Industry Organization, Vol. 22(4), pp. 129-170. 


\section{Appendix}

\section{A1. Process of Retail Payments: A Diagram}

Figure 1: Process of Payments

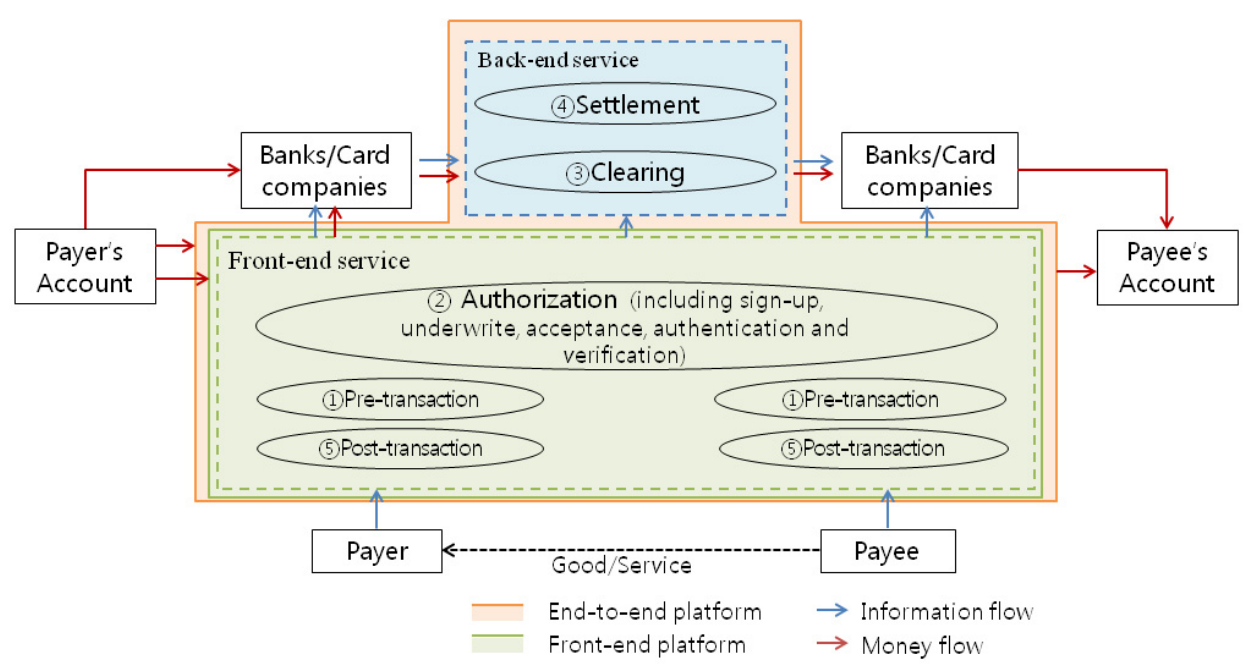

Source: Jun and Yeo (2016)

\section{A2. Proof of Proposition 1}

Proof) By differentiating the equations (5) and (6) with respect to $e_{I}$ and $e_{F}$, respectively, we have two first order conditions.

$$
\begin{aligned}
\frac{\partial \Pi_{I}}{\partial e_{I}} & =\frac{\mu c x}{2}(\bar{b}-c x q(e)) p_{1}(e)+\frac{L x}{2} p_{1}(e)-c x^{2} L q(e) p_{1}(e)-1 \\
& =\frac{\mu c x}{2}(\bar{b}-c x q(e)) p_{1}(e)+\frac{L x}{2}(\bar{b}-2 c x q(e)) p_{1}(e)-1 \\
& =0
\end{aligned}
$$




$$
\frac{\partial \Pi_{F}}{\partial e_{F}}=\frac{(1-\mu) c x}{2}(\bar{b}-c x q(e)) p_{2}(e)-1=0
$$

Under Assumption 1, i), ii), the first two terms in (29) and the first term in (30) are positive and decreasing in $e_{I}$ as long as $\bar{b}-2 c x q(e)>0$ and thus $\bar{b}-\operatorname{cxq}(e)>0$.

This implies that for small $x>0$, the optimal $e_{I}$ and $e_{F}$ are uniquely defined given $e_{I}$ and $e_{F}$, respectively.

For the existence and uniqueness of Nash equilibrium, consider the signs of cross derivative of $\Pi_{I}$ and $\Pi_{F}$.

$$
\begin{gathered}
\frac{\partial^{2} \Pi_{I}}{\partial e_{I} \partial e_{F}}=\frac{\mu c^{2} x^{2}}{2} p_{1}(e) p_{2}(e)+\frac{\mu c x}{2}(\bar{b}-c x q(e)) p_{12}(e) \\
+c x^{2} L p_{1}(e) p_{2}(e)+\frac{L x}{2}(\bar{b}-2 c x q(e)) p_{12}(e) \\
>0 \\
\frac{\partial^{2} \Pi_{F}}{\partial e_{I} \partial e_{F}}=\frac{(1-\mu) c^{2} x^{2}}{2} p_{1}(e) p_{2}(e)+\frac{\mu c x}{2}(\bar{b}-c x q(e)) p_{12}(e)>0
\end{gathered}
$$

The inequalities hold due to Assumption 1, iii). This implies that the best response functions of $\mathrm{I}$ and $\mathrm{F}$ are monotone upward sloping and exhibit increasing differences, which guarantees the existence and uniqueness of the Nash equilibrium (See Vives (2000) and Topkis (1998)). 


\section{$<$ Abstract in Korean>}

\section{소액결제시장에서의 정보접근 권한 및 금융사고에 대한 책임이 금융보안 투자 유인에 미치는 영향에 관한 연구}

\section{윤 경 수*, 전 주 용**}

핀테크를 이용한 소액결제 서비스는 이용자들의 편의성을 향상시켰으나, 결제시스템에 참여하는 기관의 수가 증가하고 단계도 복잡해지면서 금융사고 발생위험 가능성도 함께 부각되고 있다. 이에 본 연구에서는 이론모형을 구성하고 분석하여 보안투자 유인 및 결제의 안정성을 제고할 수 있는 방안을 모색한다. 소액결제시장은 핀테크 기업과 금융회사 간의 복점경쟁 형태이며, 신규 진입자인 핀테크 기업은 서비스 제공을 위하여 기존 사업자인 금융 회사가 보유하고 있는 지급결제 인프라에 대한 접근이 필요하다고 설정한다. 벤치마크로 (i) 소비자 수수료에 기반한 사업모형을 설정하고 이를 (ii) 소비자 로부터의 간접적인 수익에 기반한 사업모형(국내 대다수 핀테크 소액결제 사업모형)과 비교분석을 수행하였다. 그 결과, 금융회사에 지급하는 건당 비용이 일정하다면 소비자들의 정보를 활용(빅데이터 분석 등)하여 핀테크 사업자의 수익성 증대가 가능한 간접적 수익기반 사업모형에서 핀테크 사업 자가 안정적으로 결제시스템을 운용할 유인이 보다 높다는 결론을 도출했다. 즉, 핀테크 사업자에게 소비자 관련 정보접근 권한과 결제관련 사고에 따른 책임을 동시에 부여함으로써 책임과 권한 사이의 균형을 맞춰주고 외부성의 내부화를 통한 적정수준의 보안투자 유도가 가능하다는 것이다.

한편, 국내 현행 법규에서는 정보접근 권한 및 금융사고에 대한 책임을 모두 금융회사에게만 부여하고 있다. 이는 우월적 지위에 있는 금융회사가 영세한 핀테크 사업자에게 책임 전가를 방지하는 순기능은 있으나, 적정 수준의 보안 투자를 어렵게 하는 요인으로 작용할 수도 있다는 시사점을 제시 한다.

핵심 주제어: 소액결제시스템, 금융사고, 책임, 핀테크

JEL Classification: G23, G28, D43, L22

\footnotetext{
* 대구대학교 경제학과 교수

** 교신저자, 한국은행 경제연구원 미시제도연구실 부연구위원
}

본 연구내용은 집필자의 개인의견이며 한국은행의 공식견해와는 무관합니다. 따라서 본 논문의 내용을 보도하거나 인용할 경우에는 집필자명을 반드시 명시하여 주시기 바랍니다. 


\section{$\mathrm{BOK}$ 경제연구 발간목록}

한국은행 경제연구원에서는 Working Paper인 ${ }^{\mathrm{B} B O K}$ 경제연구』를 수시로 발간하고 있습니다. 『BOK 경제연구』는 주요 경제 현상 및 정책 효과에 대한 직관적 설명 뿐 아니라 깊이 있는 이론 또는 실증 분석을 제공함으로써 엄밀한 논증에 초점을 두는 학술논문 형태의 연구이며 한국은행 직원 및 한국은행 연구용역사업의 연구 결과물이 수록되고 있습니다.

${ }^{\circledR} \mathrm{BOK}$ 경제연구』는 한국은행 경제연구원 홈페이지(http://imer.bok.or.kr)에서 다운로드하여 보실 수 있습니다.

제2014-1 Network Indicators for Monitoring Intraday Liquidity in BOK-Wire+

2 중소기업에 대한 신용정책 효과

3 경제충격 효과의 산업간 공행성 분석

4 서비스업 발전을 통한 내외수 균형성장: 기대효과 및 리스크

5 Cross-country-heterogeneous and Time-varying Effects of Unconventional Monetary Policies in AEs on Portfolio Inflows to EMEs

6 인터넷뱅킹, 결제성예금 및 은행 수익성과의 관계 분석

7 Dissecting Foreign Bank Lending Behavior During the 2008-2009 Crisis

8 The Impact of Foreign Banks on Monetary Policy Transmission during the Global Financial Crisis of 2008-2009: Evidence from Korea

9 Welfare Cost of Business Cycles in Economies with Individual Consumption Risk

10 Investor Trading Behavior Around the Time of Geopolitical Risk Events: Evidence from South Korea

11 Imported-Inputs Channel of Exchange Rate Pass-Through: Evidence from Korean Firm-Level Pricing Survey
Seungjin Baek

Kimmo Soram ki . Jaeho Yoon

정호성·임호성

황선웅·민성환 ·

신동현 · 김기호

김승원 · 황광명

Kyoungsoo Yoon •

Christophe Hurlin

이동규·전봉걸

Moon Jung Choi •

Eva Gutierrez •

Maria Soledad Martinez Peria

Bang Nam Jeon •

Hosung Lim. Ji Wu

Martin Ellison •

Thomas J. Sargent

Young Han Kim •

Hosung Jung

Jae Bin Ahn -

Chang-Gui Park 


\begin{tabular}{|c|c|c|}
\hline 제2014-12 & 비대칭 금리기간구조에 대한 실증분석 & 김기호 \\
\hline 13 & $\begin{array}{l}\text { The Effects of Globalization } \\
\text { on Macroeconomic Dynamics } \\
\text { in a Trade-Dependent Economy: } \\
\text { the Case of Korea }\end{array}$ & Fabio Milani $\cdot$ Sung Ho Park \\
\hline 14 & $\begin{array}{l}\text { 국제 포트폴리오투자 행태 분석: 채권-주식 } \\
\text { 투자자금간 상호관계를 중심으로 }\end{array}$ & 이주용·김근영 \\
\hline 15 & $\begin{array}{l}\text { 북한 경제의 추격 성장 가능성과 } \\
\text { 정책 선택 시나리오 }\end{array}$ & 이근 · 최지영 \\
\hline 16 & $\begin{array}{l}\text { Mapping Korea's International Linkages } \\
\text { using Generalised Connectedness Measures }\end{array}$ & Hail Park $\cdot$ Yongcheol Shin \\
\hline 17 & $\begin{array}{l}\text { 국제자본이동 하에서 환율신축성과 } \\
\text { 경상수지 조정: 국가패널 분석 }\end{array}$ & 김근영 \\
\hline 18 & $\begin{array}{l}\text { 외국인 투자자가 외환시장과 주식시장 간 } \\
\text { 유동성 동행화에 미치는 영향 }\end{array}$ & 김준한 $\cdot$ 이지은 \\
\hline 19 & $\begin{array}{l}\text { Forecasting the Term Structure } \\
\text { of Government Bond Yields } \\
\text { Using Credit Spreads and Structural Breaks }\end{array}$ & $\begin{array}{l}\text { Azamat Abdymomunov } \\
\text { Kyu Ho Kang } \\
\text { Ki Jeong Kim }\end{array}$ \\
\hline 20 & $\begin{array}{l}\text { Impact of Demographic Change } \\
\text { upon the Sustainability of Fiscal Policy }\end{array}$ & $\begin{array}{l}\text { Younggak } \mathrm{Kim} \cdot \\
\text { Myoung Chul Kim } \\
\text { Seongyong Im }\end{array}$ \\
\hline 21 & $\begin{array}{l}\text { The Impact of Population Aging } \\
\text { on the Countercyclical Fiscal Stance in Korea, } \\
\text { with a Focus on the Automatic Stabilizer }\end{array}$ & $\begin{array}{l}\text { Tae-Jeong Kim } \cdot \\
\text { Mihye Lee } \cdot \text { Robert Dekle }\end{array}$ \\
\hline 22 & $\begin{array}{l}\text { 미 연준과 유럽중앙은행의 비전통적 통화정책 } \\
\text { 수행원칙에 관한 고찰 }\end{array}$ & 김병기·김진일 \\
\hline 23 & $\begin{array}{l}\text { 우리나라 일반인의 인플레이션 기대 형성 } \\
\text { 행태 분석 }\end{array}$ & 이한규·최진호 \\
\hline
\end{tabular}


제2014-24 Nonlinearity in Nexus between

Working Hours and Productivity

25 Strategies for Reforming Korea's Labor Market to Foster Growth

26 글로벌 금융위기 이후 성장잠재력 확충: 2014 한국은행 국제컨퍼런스 결과보고서

27 인구구조 변화가 경제성장률에 미치는 영향: 자본이동의 역할에 대한 논의를 중심으로

28 Safe Assets

29 확장된 실업지표를 이용한 우리나라 노동시장에서의 이력현상 분석

Entropy of Global Financial Linkages

31 International Currencies Past, Present and Future: Two Views from Economic History

32 금융체제 이행 및 통합 사례:

남북한 금융통합에 대한 시사점

Measuring Price-Level Uncertainty and Instability in the U.S., 1850-2012

고용보호제도가 노동시장 이원화

및 노동생산성에 미치는 영향

35 해외충격시 외화예금의 역할 : 주요 신흥국 신용스프레드에 미치는 영향을 중심으로 Emerging Market Economies, and Their Policy Responses
Dongyeol Lee

Hyunjoon Lim

Mai Dao · Davide Furceri •

Jisoo Hwang

Meeyeon Kim •

Tae-Jeong Kim

한국은행 경제연구원

손종칠

Robert J. Barro

김현학 · 황광명

Daeyup Lee

Barry Eichengreen

김병연

Timothy Cogley •

Thomas J. Sargent

김승원

정호성 - 우준명

김인수 · 이명수

황광명 - 김경민 -

노충식·김미진

Woon Gyu Choi •

Taesu Kang •

Geun-Young Kim •

Byongju Lee 
제2015-1 글로벌 금융위기 이후 주요국

통화정책 운영체계의 변화

2 미국 장기시장금리 변동이 우리나라 금리기간구조에 미치는 영향 분석 및 정책적 시사점

3 직간접 무역연계성을 통한 해외충격의 우리나라 수출입 파급효과 분석

4 통화정책 효과의 지역적 차이

5 수입중간재의 비용효과를 고려한 환율변동과 수출가격 간의 관계

6 중앙은행의 정책금리 발표가 주식시장 유동성에 미치는 영향

7 은행 건전성지표의 변동요인과 거시건전성 규제의 영향

8 Price Discovery and Foreign Participation in The Republic of Korea's Government Bond Futures and Cash Markets

9 규제가 노동생산성에 미치는 영향:

한국의 산업패널 자료를 이용한 실증분석

10 인구 고령화와 정년연장 연구

(세대 간 중첩모형(OLG)을 이용한 정량 분석)

11 예측조합 및 밀도함수에 의한 소비자물가 상승률 전망

12 인플레이션 동학과 통화정책

13 Failure Risk and the Cross-Section of Hedge Fund Returns

14 Global Liquidity and Commodity Prices

15 Foreign Ownership, Legal System and Stock Market Liquidity
김병기·김인수

강규호·오형석

최문정·김근영

김기호

김경민

이지은

강종구

Jaehun Choi - Hosung Lim •

Rogelio Jr. Mercado •

Cyn-Young Park

이동렬· 최종일·이종한

홍재화 - 강태수

김현학

우준명

Jung-Min Kim

Hyunju Kang •

Bok-Keun $\mathrm{Yu}$.

Jongmin $\mathrm{Yu}$

Jieun Lee $\cdot$ Kee H. Chung 
제2015-16 바젤 II 은행 경기대응완충자본 규제의 기준지표에 대한 연구

17 우리나라 대출 수요와 공급의 변동요인 분석

18 북한 인구구조의 변화 추이와 시사점

19 Entry of Non-financial Firms and Competition in the Retail Payments Market

20 Monetary Policy Regime Change and Regional Inflation Dynamics: Looking through the Lens of Sector-Level Data for Korea

21 Costs of Foreign Capital Flows in Emerging Market Economies: Unexpected Economic Growth and Increased Financial Market Volatility

22 글로벌 금리 정상화와 통화정책 과제: 2015년 한국은행 국제컨퍼런스 결과보고서

23 The Effects of Global Liquidity on Global Imbalances

24 실물경기를 고려한 내재 유동성 측정

25 Deflation and Monetary Policy

26 Macroeconomic Shocks and Dynamics of Labor Markets in Korea

27 Reference Rates and Monetary Policy Effectiveness in Korea

28 Energy Efficiency and Firm Growth

29 An Analysis of Trade Patterns in East Asia and the Effects of the Real Exchange Rate Movements

30 Forecasting Financial Stress Indices in Korea: A Factor Model Approach
서현덕·이정연

강종구 · 임호성

최지영

Jooyong Jun

Chi-Young Choi •

Joo Yong Lee

Roisin O'Sullivan

Kyoungsoo Yoon • Jayoung Kim

한국은행 경제연구원

Marie-Louise DJIGBENOU-KRE •

Hail Park

우준명·이지은

Barry Eichengreen

Tae Bong Kim •

Hangyu Lee

Heung Soon Jung •

Dong Jin Lee .

Tae Hyo Gwon .

Se Jin Yun

Bongseok Choi •

Wooyoung Park.

Bok-Keun Yu

Moon Jung Choi •

Geun-Young Kim • Joo Yong Lee

Hyeongwoo Kim • Hyun Hak Kim. Wen Shi 
제2016-1 The Spillover Effects of U.S. Monetary Policy on Emerging Market Economies: Breaks, Asymmetries and Fundamentals

2 Pass-Through of Imported Input Prices to Domestic Producer Prices:

Evidence from Sector-Level Data

3 Spillovers from U.S. Unconventional Monetary Policy and Its Normalization to Emerging Markets: A Capital Flow Perspective

4 Stock Returns and Mutual Fund Flows in the Korean Financial Market:

A System Approach

5 정책금리 변동이 성별-세대별 고용률에 미치는 영향

6 From Firm-level Imports to Aggregate Productivity: Evidence from Korean Manufacturing Firms Data

7 자유무역협정(FTA)이 한국 기업의 기업내 무역에 미친 효과

8 The Relation Between Monetary and Macroprudential Policy

9 조세피난처 투자자가 투자 기업 및 주식 시장에 미치는 영향

10 주택실거래 자료를 이용한 주택부문 거시 건전성 정책 효과 분석

11 Does Intra-Regional Trade Matter in Regional Stock Markets?: New Evidence from Asia-Pacific Region

12 Liability, Information, and Anti-fraud Investment in a Layered Retail Payment Structure
Geun-Young Kim •

Hail Park •

Peter Tillmann

JaeBin Ahn •

Chang-Gui Park •

Chanho Park

Sangwon Suh $\cdot$

Byung-Soo Koo

Jaebeom Kim •

Jung-Min Kim

정성엽

JaeBin Ahn •

Moon Jung Choi

전봉걸 - 김은숙 - 이주용

Jong Ku Kang

정호성·김순호

정호성·이지은

Sei-Wan Kim • Moon Jung Choi

Kyoung-Soo Yoon • Jooyong Jun 